\title{
Research on Differences of Efficiencies of Chinese Commercial Banks
}

\author{
Weiyi $\mathbf{J i}^{\mathbf{1}, \mathbf{a}}$ \\ ${ }^{1}$ Wenzhou Business College, Wenzhou, 325035, China
}

Keywords:Bank efficiency, DEA model, All elements efficiency model

\begin{abstract}
With the accelerated pace of the global economic integration and China's "Belt and Road" policy, the opening degree of China is gradually increasing. The tendency is obvious that Chinese banking industry is directly facing the competition pressure of the international mature financial market. Bank efficiency measures the effectiveness of bank input and output, reflecting the competitiveness of banks. Taking the seven-years data of ten commercial banks in China as the research object, this paper uses the relevant economic theory, data envelopment model and all elements efficiency model and analyses the operating efficiency and overall efficiency of each sample bank based on the method of deapto provide some constructive suggestions according to the analysis results.
\end{abstract}

\section{Research Background and Significance}

Banking plays an important role in the national economy. Bank efficiency measures the efficiency of input and output of banks, reflecting the competitiveness of banks to a certain extent. The efficiency of commercial banks directly affectsthe competitiveness of the incidence risk. The study of the factors that affect the efficiency of banks can not only provide technical support for the development of the banks, but also can provide a theoretical basis for the policy-making of financial regulatory institutions. It is the practical significance of this research.

\section{Subject Theory Basis}

The macro-control policy in China's market economy has a great impact on financial institutions, which comes from the national monetary policy, fiscal policy, credit environment and so on. A good credit environment plays a positive role in the management and efficiency promotion of commercial banks. The micro factors of the commercial bank mainly include the factors of the scale, asset allocation, asset quality, profitability, innovation capability and corporate governances.

\section{Evaluation Method of Commercial Bank Efficiency}

DEA Theory.DEA (Data Envelopment Analysis) is applied to evaluate the relative efficiencies of several units with multi input and output departments. DEA method can be used to judge the relative locations of the decision units and the efficient production by the linear programming method,but also can reflect many valuable management information, which is one of the best methods in terms of application scope and effect.

DEA Model.Assume there are $n$ commercial banks. We select $p$ input indicators and q output indicator. $X_{i k}$ and $Y_{j k}$ respectively represent the ith input indicator and jth output indicator of the kth commercial bank. $v_{i}$ represents the ith input; the $u_{j}$ represents the jth output; $w_{0}$ represents the relative efficiency. The CRS model is shown as follows: 


$$
\left\{\begin{aligned}
& \max : \mathrm{w}_{0}=\frac{\sum_{j=1}^{\mathrm{q}} \mathrm{u}_{\mathrm{j}} \mathrm{y}_{\mathrm{j}}}{\sum_{\mathrm{i}=1}^{\mathrm{p}} \mathrm{v}_{\mathrm{i}} \mathrm{x}_{\mathrm{i}}} \\
& \text { s.t. } \quad \frac{\sum_{\mathrm{j}=1}^{\mathrm{q}} \mathrm{u}_{\mathrm{j}} \mathrm{y}_{\mathrm{jk}}}{\sum_{\mathrm{i}=1}^{\mathrm{p}} \mathrm{v}_{\mathrm{i}} \mathrm{x}_{\mathrm{ik}}} \leq 1 \\
& \mathrm{v}_{\mathrm{j}} \mathrm{j}_{\mathrm{i}} \geq \varepsilon \\
& \mathrm{k}=1,2, \cdots, \mathrm{n} \\
& \mathrm{r}=1,2, \cdots, \mathrm{q} \\
& \mathrm{i}=1,2, \cdots, \mathrm{p}
\end{aligned}\right.
$$

The VRS model expresses the technical efficiency as the product of the scale efficiency and pure efficiency. The model is as follows:

$$
\left\{\begin{array}{cc}
\max : & \mathrm{w}_{0}=\frac{\sum_{\mathrm{j}=1}^{\mathrm{q}} \mathrm{u}_{\mathrm{j}} \mathrm{y}_{\mathrm{j} 0}-\mathrm{u}_{0}}{\sum_{\mathrm{i}=1}^{\mathrm{p}} \mathrm{v}_{\mathrm{i}} \mathrm{x}_{\mathrm{i} 0}} \\
\text { s.t. } \quad & \frac{\sum_{\mathrm{j}=1}^{\mathrm{q}} \mathrm{u}_{\mathrm{j}} \mathrm{y}_{\mathrm{jk}}-\mathrm{u}_{0}}{\sum_{\mathrm{i}=1}^{\mathrm{p}} \mathrm{v}_{\mathrm{i}} \mathrm{x}_{\mathrm{ik}}} \leq 1 \\
& \mathrm{v}_{\mathrm{j}} \mathrm{j}_{\mathrm{i}} \geq \varepsilon \\
\mathrm{k}=1,2, \cdots, \mathrm{n} \\
\mathrm{r}=1,2, \cdots, \mathrm{q} \\
\mathrm{i}=1,2, \cdots, \mathrm{p}
\end{array}\right.
$$

Malmquist Model. The Malmquist index method integrate the indicator data with the DEA model to conduct the all elements analysis to measure the gap between the practical value and the optimal value. It is a dynamic analysis method. According to the distance function,

$$
\mathrm{d}^{\mathrm{t}}(\mathrm{x}, \mathrm{y})=\min \left\{\theta: \frac{\mathrm{y}}{\theta} \in \mathrm{U}(\mathrm{x})\right\}
$$

We deduce the Malmquist efficiency transformation formula:

$$
M_{0}^{t, t+1}\left(x_{t+1}, y_{t+1}, x_{t}, y_{t}\right)=\frac{d_{0}^{t+1}\left(x_{t+1}, y_{t+1}\right)}{d_{0}^{t}\left(x_{t}, y_{t}\right)} \times\left[\frac{d_{0}^{t}\left(x_{t+1}, y_{t+1}\right) \times d_{0}^{t}\left(x_{t}, y_{t}\right)}{d_{0}^{t+1}\left(x_{t+1}, y_{t+1}\right) \times d_{0}^{t+1}\left(x_{t}, y_{t}\right)}\right]^{\frac{1}{2}}
$$

Among the above formula, the $\mathrm{M}_{0}^{\mathrm{t}, \mathrm{t}+1}\left(\mathrm{x}_{\mathrm{t}+1}, \mathrm{y}_{\mathrm{t}+1}, \mathrm{x}_{\mathrm{t}}, \mathrm{y}_{\mathrm{t}}\right)$ is the efficiency transformation indicator; $\mathrm{x}$ and $\mathrm{y}$ respectively represent input and output indicators; $\mathrm{t}$ and $\mathrm{t}+1$ represent the analysis indicator periods. $d_{0}^{t+1}\left(x_{t}, y_{t}\right)$ is the efficiency level of the period of $t+1$ for the reference of period of t.Therefore, when $\mathrm{M}$ is bigger than one, the efficiency is increasing; when $\mathrm{M}$ is smaller than one, the efficiency is decreasing; when $\mathrm{M}$ equals to one, the efficiency has no change.

Selection Method of Input and Output Indices.The production method, the intermediary method, the asset method and the added value method are the common selection method of input and output indices.Taking full account of the development characteristics of China's commercial banks, this paper selects the total assets, total deposits and operating income as input indicators, and the total loans and the profit before tax as output indicators.

\section{Analysis of Commercial Bank Efficiency}

Samples and Indices Selection.Taking ten big commercial banks in China as the sample, we select the indicator data from 2010 to 2016 to do the research. The collected data in the paper comes from the Wind database, the website of national data and the annual reports of the sample commercial banks. 
Table 1. Descriptive statistics of the variables (unit: billion Yuan)

\begin{tabular}{|lllrrrr|}
\hline & Variable & Index & Average & $\begin{array}{l}\text { Standard } \\
\text { deviation }\end{array}$ & Maximum value & \multicolumn{2}{l|}{$\begin{array}{l}\text { Minimum } \\
\text { value }\end{array}$} \\
\hline X1 & Total assets & 8598.631 & 6372.826 & 24137.265 & 727.61 \\
$\begin{array}{l}\text { Input } \\
\text { variables }\end{array}$ & X2 & Total deposits & 6261.346 & 4936.904 & 162894.219 & 562.912 \\
X3 & $\begin{array}{l}\text { Business } \\
\text { income }\end{array}$ & 257.328 & 199.135 & 697.647 & 18.022 \\
vatput & Y1 & Total loans & 4467.904 & 3503.336 & 13056.85 & 407.391 \\
\hline
\end{tabular}

Analysis of Sample Efficiency Based on DEA Model.According to the DEA model in the third chapter, we use the Deap2.1 software to analyze the sample data categorized by the year. The analysis results are shown in Table 2, Table 3 and Table 4.

Table 2. Technical efficiency transformation of the Chinese commercial banks from 2010 to 2016

\begin{tabular}{|c|c|c|c|c|c|c|c|c|}
\hline \begin{tabular}{|ll} 
Name & Year \\
\end{tabular} & 2010 & 2011 & 2012 & 2013 & 2014 & 2015 & 2016 & Average \\
\hline $\begin{array}{c}\text { Industrial and Commercial } \\
\text { Bank of China }\end{array}$ & 0.843 & 1 & 1 & 1 & 1 & 1 & 1 & 0.978 \\
\hline China Construction Bank & 1 & 1 & 1 & 1 & 1 & 1 & 0.975 & 0.996 \\
\hline Bank of Communications & 1 & 1 & 1 & 1 & 1 & 1 & 0.830 & 0.976 \\
\hline Agricultural Bank of China & 0.764 & 0.820 & 0.842 & 0.889 & 0.901 & 0.903 & 0.943 & 0.866 \\
\hline Pingan Bank & 0.952 & 1 & 0.906 & 0.881 & 0.843 & 0.885 & 0.839 & 0.901 \\
\hline $\begin{array}{l}\text { Shanghai Pudong } \\
\text { Development Bank }\end{array}$ & 0.909 & 1 & 1 & 0.950 & 0.984 & 1 & 0.920 & 0.966 \\
\hline Industrial Bank & 0.972 & 1 & 1 & 1 & 1 & 1 & 0.853 & 0.975 \\
\hline China Merchants Bank & 1 & 0.982 & 1 & 1 & 0.982 & 1 & 0.930 & 0.985 \\
\hline Bank of China & 0.965 & 1 & 0.982 & 0.994 & 1 & 1 & 1 & 0.992 \\
\hline China Citic Bank & 1 & 1 & 1 & 0.967 & 0.954 & 0.957 & 0.932 & 0.973 \\
\hline
\end{tabular}


Table 3. Pure technical efficiency transformation of the Chinese commercial banks from 2010 to

\begin{tabular}{|c|c|c|c|c|c|c|c|c|}
\hline Name $\quad$ Year & 2010 & 2011 & 2012 & 2013 & 2014 & 2015 & 2016 & Average \\
\hline $\begin{array}{c}\text { Industrial and Commercial } \\
\text { Bank of China }\end{array}$ & 1 & 1 & 1 & 1 & 1 & 1 & 1 & 1 \\
\hline China Construction Bank & 1 & 1 & 1 & 1 & 1 & 1 & 0.983 & 0.998 \\
\hline Bank of Communications & 1 & 1 & 1 & 1 & 1 & 1 & 0.979 & 0.997 \\
\hline Agricultural Bank of China & 0.851 & 0.869 & 0.870 & 0.889 & 0.902 & 0.904 & 0.947 & 0.890 \\
\hline Pingan Bank & 1 & 1 & 1 & 1 & 1 & 1 & 1 & 1 \\
\hline $\begin{array}{l}\text { Shanghai Pudong } \\
\text { Development Bank }\end{array}$ & 0.920 & 1 & 1 & 0.991 & 1 & 1 & 1 & 0.987 \\
\hline Industrial Bank & 1 & 1 & 1 & 1 & 1 & 1 & 1 & 1 \\
\hline China Merchants Bank & 1 & 1 & 1 & 1 & 1 & 1 & 1 & 1 \\
\hline Bank of China & 1 & 1 & 1 & 1 & 1 & 1 & 1 & 1 \\
\hline China Citic Bank & 1 & 1 & 1 & 1 & 1 & 1 & 1 & 1 \\
\hline \multicolumn{9}{|c|}{ Table 4. Scale efficiency transformation of the Chinese commercial banks from 2010 to 2016} \\
\hline \begin{tabular}{|ll} 
Name & Year \\
\end{tabular} & 2010 & 2011 & 2012 & 2013 & 2014 & 2015 & 2016 & Average \\
\hline $\begin{array}{c}\text { Industrial and Commercial } \\
\text { Bank of China }\end{array}$ & 0.843 & 1 & 1 & 1 & 1 & 1 & 1 & 0.978 \\
\hline China Construction Bank & 1 & 1 & 1 & 1 & 1 & 1 & 0.991 & 0.999 \\
\hline Bank of Communications & 1 & 1 & 1 & 1 & 1 & 1 & 0.847 & 0.978 \\
\hline Agricultural Bank of China & 0.897 & 0.944 & 0.969 & 0.999 & 0.999 & 0.998 & 0.996 & 0.972 \\
\hline Pingan Bank & 0.952 & 1 & 0.906 & 0.881 & 0.843 & 0.885 & 0.839 & 0.901 \\
\hline $\begin{array}{l}\text { Shanghai Pudong } \\
\text { Development Bank }\end{array}$ & 0.989 & 1 & 1 & 0.959 & 0.984 & 1 & 0.920 & 0.979 \\
\hline Industrial Bank & 0.972 & 1 & 1 & 1 & 1 & 1 & 0.853 & 0.975 \\
\hline China Merchants Bank & 1 & 1 & 1 & 1 & 0.982 & 1 & 0.930 & 0.987 \\
\hline Bank of China & 0.965 & 0.982 & 0.982 & 0.994 & 1 & 1 & 1 & 0.989 \\
\hline China Citic Bank & 1 & 1 & 1 & 0.967 & 0.954 & 0.957 & 0.932 & 0.973 \\
\hline
\end{tabular}

Analysis of Sample Efficiency Based on Malmquist Model. According to the Malmquist model in the third chapter, we use the Deap2.1 software to analyze the sample data categorized by the year. The analysis results are shown in Table 5.

Table 5. Average all elements indicators of Chinese commercial banks from 2010 to 2016

\begin{tabular}{cccccc}
\hline Time & $\begin{array}{c}\text { Technical } \\
\text { efficiency }\end{array}$ & $\begin{array}{c}\text { Technical } \\
\text { progress }\end{array}$ & $\begin{array}{c}\text { Pure } \\
\text { technicalefficiency }\end{array}$ & Scaleefficiency & $\begin{array}{c}\text { All } \\
\text { elementsefficiency }\end{array}$ \\
\hline $2010-2011$ & 1.044 & 0.817 & 1.011 & 1.033 & 0.853 \\
$2011-2012$ & 0.993 & 0.983 & 1.000 & 0.993 & 0.975 \\
$2012-2013$ & 0.995 & 1.048 & 1.001 & 0.994 & 1.043 \\
$2013-2014$ & 0.998 & 0.962 & 1.002 & 0.996 & 0.960 \\
$2014-2015$ & 1.009 & 0.975 & 1.000 & 1.008 & 0.984 \\
$2015-2016$ & 0.945 & 1.105 & 1.001 & 0.944 & 1.045 \\
\hline
\end{tabular}




\section{Conclusion}

This paper uses relevant theories and models, takes the ten commercial banks in China as samples, selects 350 indicators in seven years and analyses the operating efficiency and overall efficiency of each sample bank based on the method of deap. The results show that there are obvious differences among the banks in terms of technical efficiency and scale efficiency, and the overall efficiency of Chinese bank is significantly affected by technological progress. According to the analysis of the results and the reasons, this paper puts forward some suggestions as follows for the development of commercial banks in China. First, to improve the sensitivity to the macroeconomic environment; second, appropriately control the asset size; third, to enhance the technical level of business.

\section{References}

[1] Man Yuanyuan, Yang Yinsheng, Sun Wei. Commercial Banks: Effciency, Market Structureand Performance Relationship [J]. Journal of Applied Statisticsand Management, 2015, 34(1): 125-141.

[2] Chen Yihong. Efficiency Analysis of City Commercial Banks from 2009 to 2011— An Empirical Analysis based on DEA andMalmquist Index [J].Scientific Decision Making, 2013(2): 17-32.

[3] Zhang Dongchao. Efficiency Analysis ofListed Commercial Banks in China Based on DEA [J]. Exploration of Financial Theory, 2016(5): 31-40.

[4] Liu Xin, Shi Baozhu, Zou Xiang. A Study of Impact ofRiskFactors on the Efficiency of Commercial Banks in China Based on Fuzzy DEA Model [J]. 2016, 16(2): 9-17+38. 